\title{
ХІМІЯ
}

CHEMISTRY

https://doi.org/10.15407/dopovidi2021.05.090

УДК 547.814

Т.В. Шокол ${ }^{1}$, https://orcid.org/0000-0002-8483-703X

А.В. Супрун ${ }^{1}$,

С.К. Глібов ${ }^{1,2}$, https://orcid.org/0000-0002-5987-9510

В.С. Москвіна ${ }^{1}$, https://orcid.org/0000-0001-5556-9147

В.П. Хиля ${ }^{1}$, https://orcid.org/0000-0001-9438-572Х

${ }^{1}$ Київський національний університет ім. Тараса Шевченка

2 ТОВ “НВП “Снамін”, Київ

E-mail: shokol_tv@univ.kiev.ua

\section{Модифікації 7-гідрокси-3-(бензотіазол-2-іл)кумарину}

Представлено иленом-кореспондентом НАН України В.П. Хилею

Проведено модифікацію 7-гідрокси-3-(бензотіазол-2-іл)кумарину, що містить диметиламінометильну та формільну групи в 8-му положенні бензопіран-2-онового циклу, корисні для подальших структурних перетворень. Амінометилюванням 7-гідрокси-3-(бензотіазол-2-іл)кумарину за класичних умов реакиї Манніха з використанням надлишку формаліну отримані похідні системи дигідрооксазинокумарину. На основі 8-діалкіламінометил-7-гідрокси-3-(бензотіазол-2-іл)кумарину переамінуванням з бензиламінами синтезовані відповідні основи Манніха, в результаті взаємодї з енамінокетонами о-гідроксіаренів - похідні гомоізофлавону, за умов реакиії Даффа - 3-(бензотіазол-2-іл)-7-гідрокси-8-формілкумарин. Останній у реакиї з 4-нітрофенащилбромідом утворює похідну системи фуро[2,3-һ]кумарину. Досліджено рециклізації 3-(бензотіазол-2-іл)-7-гідрокси-8-(4-оксо-4Н-3-хроменілметил)-2Н-2-хроменону під дією бінуклеофілів.

Ключові слова: 7-гідрокси-3-бензотіазолілкумарин, амінометилювання, формілювання, гомоізофлавони, рещиклізачія.

Кумарини широко представлені в рослинному світі і активно застосовуються в медицині завдяки різноманітній біологічній активності. Також вони мають чудові фотофізичні властивості, такі як високий квантовий вихід, сильна флуоресценція, хороша фотостійкість, що обумовлює їх використання як барвників для біосенсибілізації та біомаркування [1]. Гетероциклічні замісники в 3-му положенні значно підвищують фотофізичні властивості кумарину. 3-Бензотіазолілкумарини активно використовуються як флуоресцентні зонди [2] і запропоновані як потенційні МЕК1 інгібітори [3].

7-Гідрокси-3-бензотіазолілкумарин було синтезовано за реакцією Кневенагеля шляхом взаємодії 2,4-дигідроксибензальдегіду з (бензотіазол-2-іл)ацетонітрилом [1-4] або 3

Ци т у в ан н я: Шокол Т.В., Супрун А.В., Глібов С.К., Москвіна В.С., Хиля В.П. Модифікації 7-гідрокси3-(бензотіазол-2-іл)кумарину. Допов. Нащ. акад. наук Укр. 2021. № 5. С. 90-98. https://doi.org/10.15407/dopovidi2021.05.090 

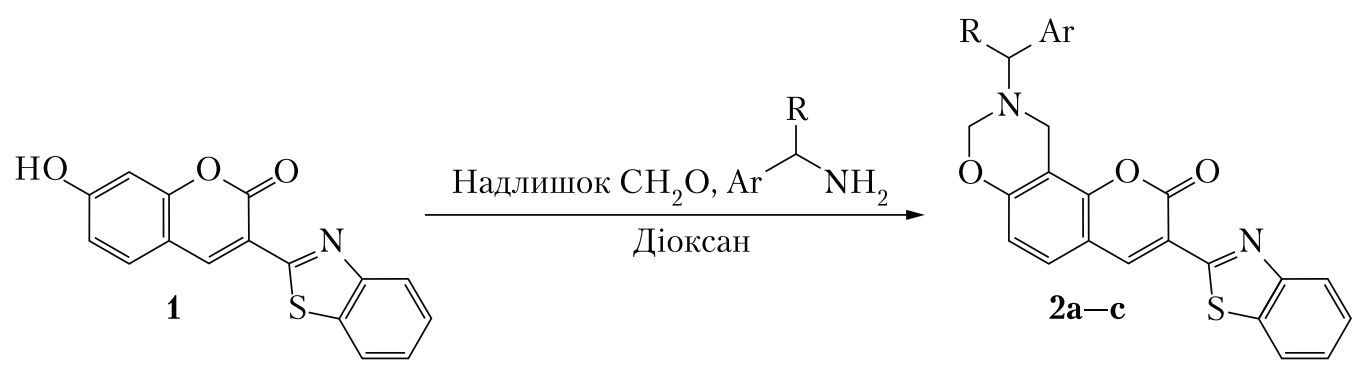

a: $\mathrm{R}=\mathrm{H}, \mathrm{Ar}=\mathrm{Ph} ; \mathbf{b}: \mathrm{R}=\mathrm{H}, \mathrm{Ar}=4-\mathrm{MeOC}_{6} \mathrm{H}_{4} ; \mathbf{c}: \mathrm{R}=\mathrm{Me}, \mathrm{Ar}=\mathrm{Ph}$

\section{Схема 1}

етил-2-бензотіазолілацетатом [5]. За другим підходом 7-гідрокси-3-бензотіазолілкумарин синтезували з 7-гідрокси-3-ціанокумарину і 2-амінотіофенолу із застосуванням мікрохвильового опромінення в оцтовій кислоті або в етанолі з каталізатором НРМо $\left(\mathrm{H}_{3} \mathrm{PMo}_{12} \mathrm{O}_{3}\right)$ [6]. Для 7-гідрокси-3-(бензотіазол-2-іл)кумарину були вивчені реакції алкілювання та ацилювання за гідроксильною групою [1, 4], амінометилювання [4, 7] та формілювання [7] по 8-му положенню, а також ціанування по 4-му положенню [3, 5].

Метою дослідження було проведення модифікацій 7-гідрокси-3-(бензотіазол-2-іл)кумарину (1) із застосуванням введених у 8-ме положення функціональних груп, корисних для подальших структурних перетворень і гетероциклізації та рециклізації на їх основі.

Амінометилювання 7-гідроксикумарину 1 за класичних умов з використанням бензиламінів і надлишку 37 \%-го розчину формаліну в діоксані привело до анелювання дигідрооксазинового циклу до ядра кумарину по грані С(7)-C(8) і утворення 3-(1,3-бензотіазол-2іл)-9-бензил-9,10-дигідро-2H,8H-хромено[8,7-e][1,3]оксазин-2-онів (2a-c) (схема 1), що підтверджується наявністю в спектрах ${ }^{1} \mathrm{H}$ ЯМР сполук $\mathbf{2 a , b}$ трьох двопротонних синглетів метиленових груп, які належать бензильній групі при 3,81-3,90 м. ч. та двом метиленовим групам дигідрооксазинового циклу при 4,13-4,16 м. ч. $\left(10-\mathrm{CH}_{2}\right)$ і 4,97-4,98 м. ч. $\left(8-\mathrm{CH}_{2}\right)$. У спектрі ${ }^{1} \mathrm{H}$ ЯМР 9-(1-фенілетил)-похідної 2с сигнали протонів дигідрооксазинового циклу, що поглинають у тих же областях, не є еквівалентними через близькість до асиметричного центру.

Як відомо, у результаті амінометилювання 7-гідроксикумарину 1 із застосуванням бісдиметиламінометану в діоксані утворюється 8-диметиламінометильна похідна 3 [4], яка була використана нами як вихідна сполука у низці хімічних перетворень.

Переамінуванням сполуки $\mathbf{3}$, проведеним при кип'ятінні з бензиламінами в діоксані протягом 2 год, отримано основи Манніха з вторинною аміногрупою - 3-(1,3-бензотіазол2-іл)-8-бензиламінометил-7-гідрокси-2H-2-хроменони 4а-с (схема 2).

У спектрах ${ }^{1}$ Н ЯМР сполук $\mathbf{4 a , b}$ на відміну від вихідного продукту $\mathbf{3}$, у спектрі якого спостерігається один двопротонний синглет метиленової групи при 4,08 м. ч., присутні два двопротонні синглети метиленових груп при 4,17-4,21 м. ч. (8- $\left.\mathrm{CH}_{2}\right)$ і 3,91-3,92 м. ч. $\left(\mathrm{CH}_{2} \mathrm{Ph}\right)$.

У результаті кип'ятіння основи Манніха 3 з енамінокетонами орто-гідроксіаренів 5 і 6 у диметилформаміді були отримані сполуки 7 і 8, що містять кумариновий і хромоновий або піранонеофлавоновий гетероцикли, зв’язані метиленовою ланкою (схема 3). 


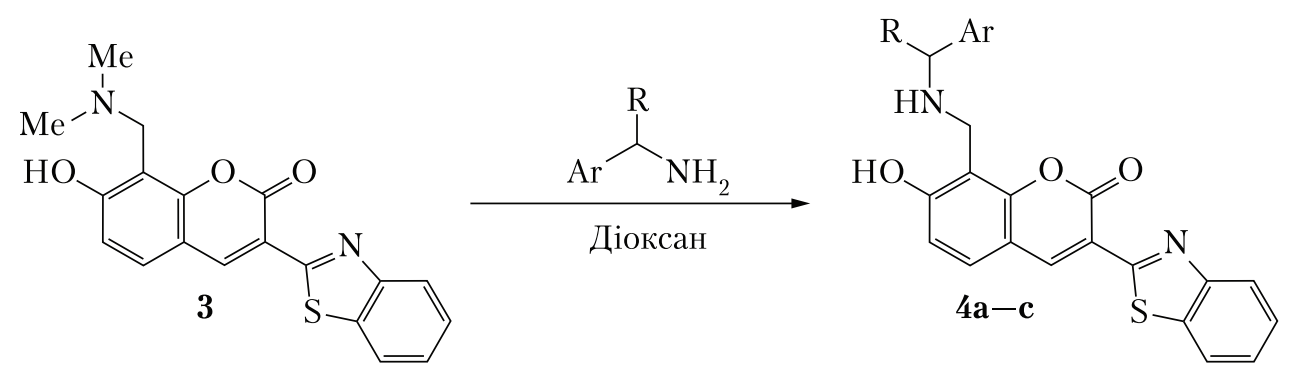

a: $\mathrm{R}=\mathrm{H}, \mathrm{Ar}=\mathrm{Ph} ; \mathbf{b}: \mathrm{R}=\mathrm{H}, \mathrm{Ar}=4-\mathrm{MeOC}_{6} \mathrm{H}_{4} ; \mathbf{c}: \mathrm{R}=\mathrm{Me}, \mathrm{Ar}=\mathrm{Ph}$

\section{Схема 2}

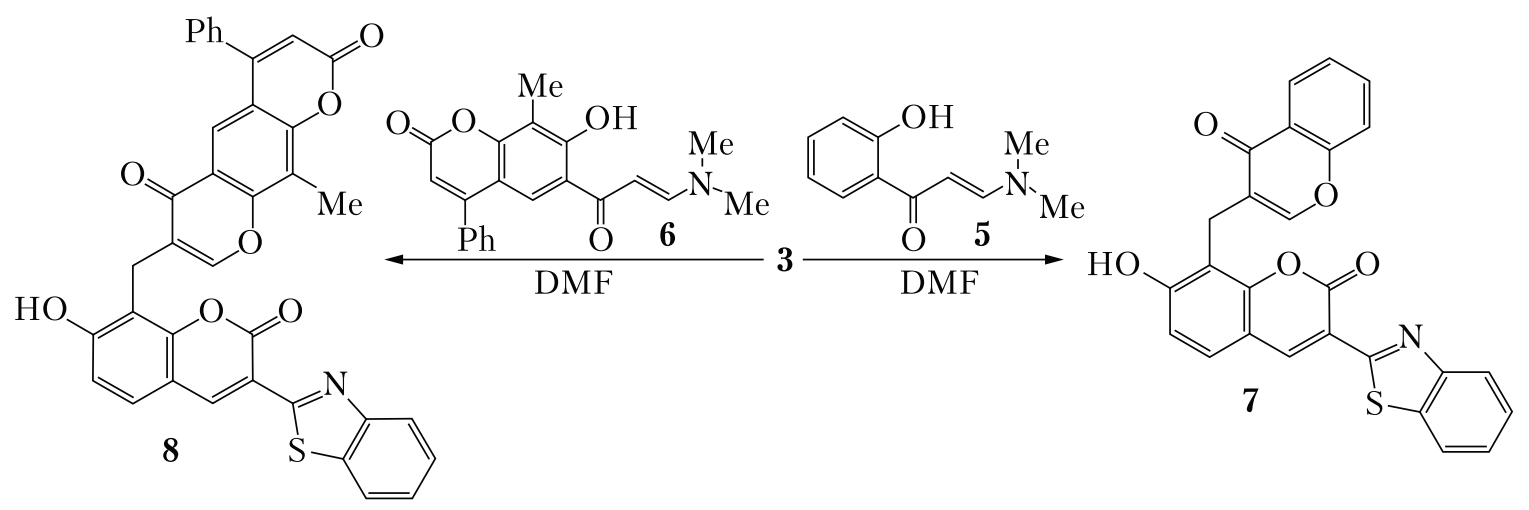

\section{Схема 3}

У спектрах ${ }^{1} \mathrm{H}$ ЯМР сполук 7, 8 двопротонний синглет метиленової групи спостерігається при 3,86-3,93 м. ч., а найслабкопольніший синглет при 10,89-10,97 м. ч. належить ОН-групі. Однопротонний синглет при 9,07-9,09 м. ч. відповідає протону Н-4 кумаринового циклу, а в області 7,81 м. ч. з’являється синглет протона хромонового ядра Н-2" (для гомоізофлавону 7) або 7,95 м. ч. (Н-8" для сполуки 8). У спектрі ${ }^{1}$ Н ЯМР сполуки 8 найсильніший синглет в області поглинання ароматичних протонів при 6,46 м. ч. належить протону Н-3" неофлавонової частини молекули.

Досліджено поведінку 3-(бензотіазол-2-іл)-7-гідрокси-8-(4-оксо-4H-3-хроменілметил)2H-2-хроменону (7) під дією бінуклеофілів. Після кипятіння сполуки 7 з надлишком гідразину гідрату в етанолі, гідрохлориду гідроксиламіну в піридині або гуанідину карбонату в диметилформаміді кумариновий цикл залишається незмінним, а хромоновий цикл зазнає рециклізації з утворенням продуктів 9, 10 та 11, що містять піразольний, ізоксазольний або піримідиновий цикли відповідно (схема 4). Це підтверджується зникненням у спектрах ${ }^{1}$ Н ЯМР сполук 9-11 сигналу протона Н-2 хромонового кільця при 7,81 м. ч., характерного для продукту 7. Натомість 3’являється уширений сигнал протона Н-5 піразольного циклу при 7,85 м. ч. (у сполуці 9), синглет протона Н-3 ізоксазольного циклу при 8,11 м. ч. (у сполуці 10) або однопротонний синглет Н-4 при 7,79 м. ч. і двопротонний синглет $\mathrm{NH}_{2}$ групи при 6,21 м. ч. піримідинового фрагмента продукту 11 та сигнал 2-ОН групи фенольного замісника. 


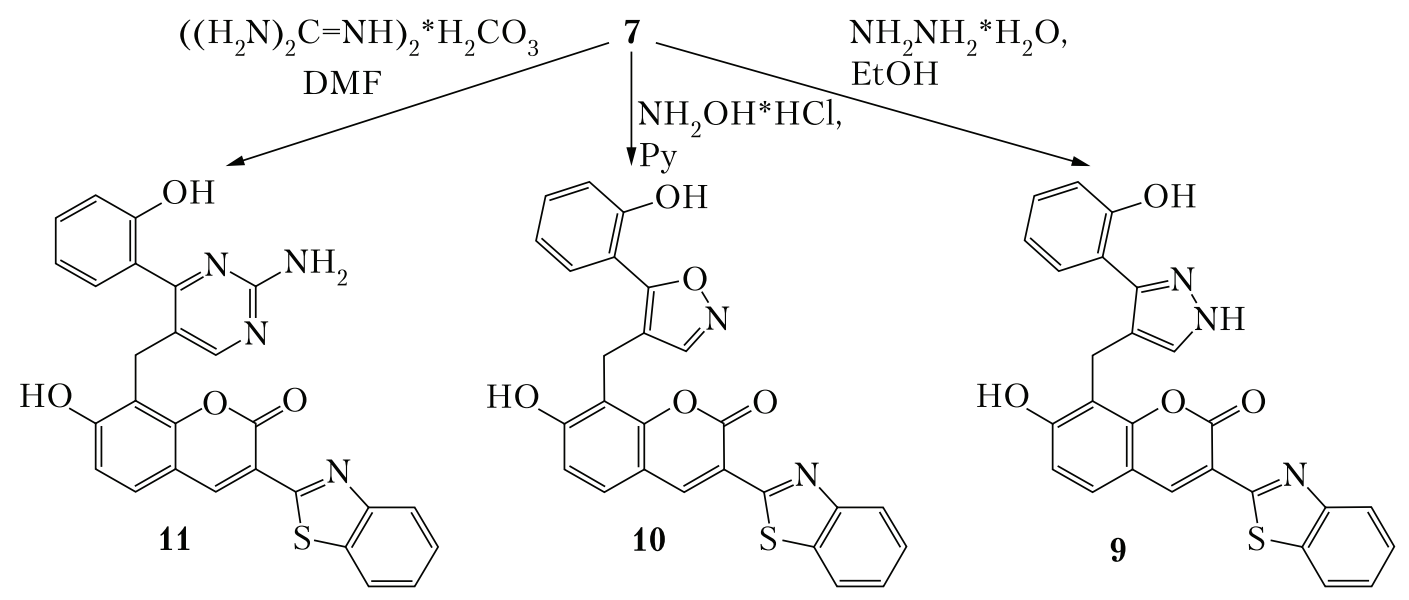

\section{Схема 4}<smiles>CN(C)Cc1c(O)ccc2cc(-c3nc4ccccc4s3)c(=O)oc12</smiles>

\section{Схема 5}<smiles>O=Cc1c(O)ccc2cc(-c3nc4ccccc4s3)c(=O)oc12</smiles><smiles>O=C(CBr)c1ccc([N+](=O)[O-])cc1</smiles><smiles>Cc1ccc([N+](=O)[O-])cc1</smiles>

13<smiles>Cc1cc2c(ccc3cc(-c4nc5ccccc5s4)c(=O)oc32)o1</smiles>

\section{Схема 6}

3 введенням основи Манніха 3 або кумарину 1 у реакцію Даффа при кип'ятінні в оцтовій кислоті з двократним надлишком уротропіну з подальшим кислотним гідролізом реакційної суміші було отримано 3-(1,3-бензотіазол-2-іл)-7-гідрокси-2-оксо-2H-8-хроменкарбальдегід (12) (схема 5).

У результаті нагрівання 7-гідрокси-8-формілкумарину 12 з 4-нітрофенацилбромідом у диметилформаміді при $100{ }^{\circ} \mathrm{C}$ у присутності карбонату калію утворився фуро[2,3- $\left.h\right]$ кумарин 13, який містить ароїльний замісник в 2-му положенні (схема 6), що підтверджується появою в спектрі ${ }^{1} \mathrm{H}$ ЯМР синглету протона Н-3 при 8,19 м. ч.

Таким чином, вивчено шляхи структурної модифікації 7-гідрокси-3-(бензотіазол-2-іл) кумарину, з використанням на першому етапі дослідження реакції амінометилювання та формілювання. На наступному етапі дослідження проведені реакції гетероциклізації 
та рециклізації із застосуванням відповідних 8-амінометил-7-гідрокси- та 8-форміл-7гідрокси-3-(бензотіазол-2-іл)кумаринів.

Експериментальна частина. Контроль за чистотою та індивідуальністю одержаних продуктів здійснювали методом ТШХ на платівках Silufol UV-254 з використанням як елюенту системи розчинників $\mathrm{CHCl}_{3}-\mathrm{MeOH}, 9$ : 1 . Спектри ${ }^{1} \mathrm{H}$ ЯМР реєстрували на приладі Varian Mercury 400 із використанням сигналу залишкового розчинника DMSO як внутрішнього стандарту. Дані елементного аналізу, що отримані за допомогою приладу "Vario Micro Cube”, відповідають розрахованим. Температуру плавлення вимірювали на блоці Кофлера. Мас-спектри реєстрували на приладі Agilent 1100 LC/MSD з хімічною іонізацією (CI).

3-(1,3-Бензотіазол-2-іл)-7-гідрокси-2Н-2-хроменон (1) і 3-(1,3-бензотіазол-2-іл)8-диметиламінометил-7-гідрокси-2H-2-хроменон (3) синтезовано за методиками, наведеними у роботі [4].

Загальна методика синтезу 3-(1,3-бензотіазол-2-іл)-9-бензил-9,10-дигідро2Н,8Н-хромено[8,7-е][1,3]оксазин-2-онів (2a-c). До 0,16 г (0,5 ммоль) 3-(1,3-бензотіазол-2-іл)-7-гідрокси-2H-2-хроменону (1) у 4 мл діоксану додали 2 ммоль відповідного бензиламіну і 4 мл 37 \%-го формаліну і кип’ятили 3 год (контроль за ТШХ). Охолодили, відфільтрували осад, промили діоксаном.

3-(1,3-Бензотіазол-2-іл)-9-бензил-9,10-дигідро-2Н,8Н-хромено[8,7-е][1,3]оксазин-2-он (2a). Вихід $62 \% . \mathrm{C}_{25} \mathrm{H}_{18} \mathrm{~N}_{2} \mathrm{O}_{3} \mathrm{~S} . T_{\text {пл }} 196-197{ }^{\circ} \mathrm{C}$ (з діоксану). Спектр ЯМР ${ }^{1} \mathrm{H}$ (400 МГц, DMSO- $d_{6}-\mathrm{CCl}_{4}, \delta$, м. д., $J /$ Г) $: 3,90\left(2 \mathrm{H}, \mathrm{c}, \mathrm{PhCH}_{2}\right), 4,16\left(2 \mathrm{H}, \mathrm{c}, 10-\mathrm{CH}_{2}\right), 4,98$ $\left(2 \mathrm{H}, \mathrm{c}, 8-\mathrm{CH}_{2}\right), 6,84$ (1H, д, $\left.J=8,8, \mathrm{H}-6\right), 7,26-7,39$ (6H, м, H- $\left.\overline{6^{\prime}}, \mathrm{Ph}\right), 7,47$ (1H, т, J = 8,0, H-5' ), $7,73$ (1Н, д, $J=8,8, \mathrm{H}-5), 7,96$ (1Н, д, $\left.J=8,4, \mathrm{H}^{-4}{ }^{\prime}\right), 7,99$ (1Н, д, $\left.J=8,4, \mathrm{H}^{7} \mathbf{7}^{\prime}\right), 9,08$ (1Н, с, Н-4). Мас-спектр, $m / z\left(I_{\text {відн }}, \%\right): 415\left[\mathrm{MH}^{+}-12\right](100)$.

3-(1,3-Бензотіазол-2-іл)-9-(4-метоксибензил)-9,10-дигідро-2Н,8Н-хромено[8,7-е] [1,3]оксазин-2-он (2b). Вихід 74\%. $\mathrm{C}_{26} \mathrm{H}_{20} \mathrm{~N}_{2} \mathrm{O}_{4} \mathrm{~S} . T_{\text {пл }} 203-204^{\circ} \mathrm{C}$ (з діоксану). Спектр ЯМР

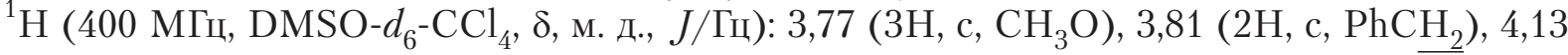
$\left(2 \mathrm{H}\right.$, с , 10- $\left.\mathrm{CH}_{2}\right), 4,97\left(2 \mathrm{H}\right.$, c, 8- $\left.\mathrm{CH}_{2}\right), 6,85$ (3Н, д, $\left.J=8,4, \mathrm{H}-6, \mathrm{H}-3^{\prime \prime}, 5^{\prime \prime}\right), 7,23(2 \mathrm{H}, \overline{\text { д, } J}=8,0$, Н-2",6"), 7,39 (1H, т, $\left.J=8,0, \mathrm{H}-6^{\prime}\right), 7,49$ (1H, т, $\left.J=8,0, \mathrm{H}-5^{\prime}\right), 7,77$ (1Н, д, $\left.J=8,4, \mathrm{H}-5\right), 7,97$ (1Н, д, $\left.J=8,0, \mathrm{H}^{-4} \mathbf{4}^{\prime}\right), 8,01$ (1Н, д, $\left.J=8,0, \mathrm{H}-7^{\prime}\right), 9,11$ (1Н, с, Н-4). Мас-спектр, $m / z\left(I_{\text {відн }} \%\right.$ ): 444,9 [ $\left.\mathrm{MH}^{+}-12\right](100)$.

3-(1,3-Бензотіазол-2-іл)-9-(1-фенілетил)-9,10-дигідро-2Н,8Н-хромено[8,7-е] [1,3]оксазин-2-он (2c). Вихід $79 \% \mathrm{C}_{26} \mathrm{H}_{20} \mathrm{~N}_{2} \mathrm{O}_{3} \mathrm{~S} . T_{\text {пл }} 104-105{ }^{\circ} \mathrm{C}$ (з діоксану). Спектр ЯМР ${ }^{1} \mathrm{H}\left(400\right.$ МГц, DMSO-d ${ }_{6}-\mathrm{CCl}_{4}, \delta$, м. д., $J /$ Г) : 1,45 (3H, д, $\left.J=7,2, \mathrm{CH}_{3}\right), 3,91(1 \mathrm{H}$, к, $\left.J=7,2, \mathrm{CHCH}_{3}\right), 3,97\left(1 \mathrm{H}\right.$, д, $\left.J=17,2,10-\mathrm{CH}_{\alpha}\right), 4,26\left(1 \mathrm{H}\right.$, д, $\left.J=17,2,10-\mathrm{CH}_{\beta}\right), 4,96(1 \mathrm{H}$, д, $\left.J=10,4,8-\mathrm{CH}_{\alpha}\right), 5,20$ (1Н, д, $\left.J=10,4,8-\mathrm{CH}_{\beta}\right), 6,83(1 \mathrm{H}$, д, $J=8,8, \mathrm{H}-6), 7,26-7,33(5 \mathrm{H}, \mathrm{м}, \mathrm{Ph})$, 7,38 (1H, т, $\left.J=8,0, \mathrm{H}^{-6} 6^{\prime}\right), 7,49$ (1H, т, $\left.J=8,0, \mathrm{H}-5^{\prime}\right), 7,74$ (1Н, д, $\left.J=8,8, \mathrm{H}-5\right), 7,97$ (1Н, д, $J=8,0$, Н-4'), 8,01 (1Н, д, $\left.J=8,0, \mathrm{H}^{-} 7^{\prime}\right), 9,01$ (1H, с, Н-4). Мас-спектр, $m / z\left(I_{\text {відн }}, \%\right): 429$ $\left[\mathrm{MH}^{+}-12\right](100)$.

Загальна методика синтезу 3-(1,3-бензотіазол-2-іл)-8-бензиламінометил-7гідрокси-2Н-2-хроменонів (4a-c). До розчину 0,18 г (0,5 ммоль) 3-(1,3-бензотіазол-2-іл)8-диметиламінометил-7-гідрокси- $2 H$-2-хроменону (3) у 3 мл діоксану додали 2,5 ммоль відповідного бензиламіну і кип'ятили 2 год (контроль за ТШХ). Охолодили, відфільтрували осад, промили діоксаном. 
3-(1,3-Бензотіазол-2-іл)-8-бензиламінометил-7-гідрокси-2Н-2-хроменон (4a). Вихід $50 \% . \mathrm{C}_{24} \mathrm{H}_{18} \mathrm{~N}_{2} \mathrm{O}_{3} \mathrm{~S} . T_{\text {пл }} 242-243{ }^{\circ} \mathrm{C}$ (з діоксану). Спектр ЯMP ${ }^{1} \mathrm{H}$ ( 400 МГц, DMSO$d_{6}-\mathrm{CCl}_{4}, \delta$, м. д., $J /$ Гц $): 3,92\left(2 \mathrm{H}, \mathrm{c}, \mathrm{PhCH}_{2}\right), 4,21\left(2 \mathrm{H}, \mathrm{c}, \mathrm{NHCH}_{2}\right), 6,61(1 \mathrm{H}$, д, $J=8,4, \mathrm{H}-6)$,

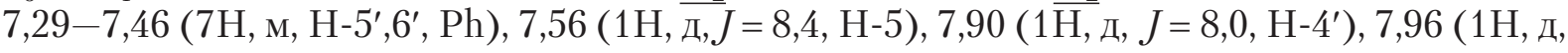
$\left.J=8,0, \mathrm{H}^{\prime} 7^{\prime}\right), 8,94(1 \mathrm{H}, \mathrm{c}, \mathrm{H}-4)$, ОН та $\mathrm{NH}$ обмінялися з $\left.\mathrm{H}_{2} \mathrm{O}\right)$. Мас-спектр, $m / z\left(I_{\text {відн }} \%\right)$ : $415[\mathrm{MH}]^{+}(100)$.

3-(1,3-Бензотіазол-2-іл) -7-гідрокси-8-(4-метоксибензиламінометил)-2Н2-хроменон (4b). Вихід $49 \%$. $\mathrm{C}_{25} \mathrm{H}_{20} \mathrm{~N}_{2} \mathrm{O}_{4} \mathrm{~S} . T_{\text {пл }} 257-258{ }^{\circ} \mathrm{C}$ ( 3 діоксану). Спектр ЯМР ${ }^{1} \mathrm{H}$ (400 МГц, DMSO- $d_{6}-\mathrm{CCl}_{4}, \delta$, м. д., $J /$ Гц): 3,77 (3H, с, $\left.\mathrm{CH}_{3} \mathrm{O}\right), 3,91\left(2 \mathrm{H}, \mathrm{c}, \mathrm{PhCH}_{2}\right), 4,17(2 \mathrm{H}, \mathrm{c}$, $\left.\mathrm{NHCH}_{2}\right), 6,54(1 \mathrm{H}$, д, $J=8,4, \mathrm{H}-6), 6,88$ (2H, д, $\left.J=8,4, \mathrm{H}-3^{\prime \prime}, 5^{\prime \prime}\right), 7,29-7,35$ (3) $7,43 \overline{(1 \mathrm{H}}$, т, $\left.J=8,0, \mathrm{H}-5^{\prime}\right), 7,53(1 \mathrm{H}$, д, $J=8,4, \mathrm{H}-5), 7,89\left(1 \mathrm{H}\right.$, д, $\left.J=8,0, \mathrm{H}-4^{\prime}\right), 7,96(1 \mathrm{H}$, д, $J=$ $\left.=8,0, \mathrm{H}^{-} 7^{\prime}\right), 8,90(1 \mathrm{H}, \mathrm{c}, \mathrm{H}-4), \mathrm{OH}$ та $\mathrm{NH}$ обмінялися з $\left.\mathrm{H}_{2} \mathrm{O}\right)$. Мас-спектр, $m / z\left(I_{\text {відн }}, \%\right)$ : $445[\mathrm{MH}]^{+}(100)$.

3-(1,3-Бензотіазол-2-іл)-7-гідрокси-8-(1-фенілетиламінометил)-2Н-2-хроменон (4c). Вихід $55 \% . \mathrm{C}_{25} \mathrm{H}_{20} \mathrm{~N}_{2} \mathrm{O}_{3} \mathrm{~S} . T_{\text {пл }} 189-190{ }^{\circ} \mathrm{C}$ (з діоксану). Спектр ЯМР ${ }^{1} \mathrm{H}$ ( 400 МГц,

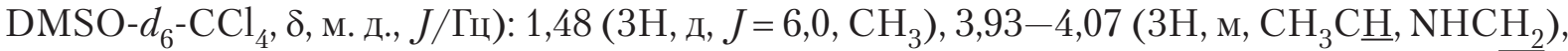
6,61 (1Н, д, $J=8,4, \mathrm{H}-6), 7,6-7,46$ (7H, м, Н-5',6', Ph), 7,57 (1Н, д, J = 8,4, Н-5), 7,91 (1) $\left.J=8,0, \mathrm{H}-4^{\prime}\right), 7,97\left(1 \mathrm{H}\right.$, д, $\left.J=8,0, \mathrm{H}-7^{\prime}\right), 8,94(1 \mathrm{H}, \mathrm{c}, \mathrm{H}-4), \mathrm{OH}$ та $\mathrm{NH}$ обмінялися з $\left.\mathrm{H}_{2} \mathrm{O}\right)$. Мас-спектр, $m / z\left(I_{\text {відн }}, \%\right): 429[\mathrm{MH}]^{+}(100)$.

3-(1,3-Бензотіазол-2-іл)-7-гідрокси-8-(4-оксо-4Н-3-хроменілметил)-2Н-2хроменон (7). До розчину 0,18 г (0,5 ммоль) 3-(1,3-бензотіазол-2-іл)-8-диметиламінометил7-гідрокси-2H-2-хроменону (3) у 2 мл диметилформаміду додали 0,1 г (0,5 ммоль) 3-диметиламіно-1-(2-гідроксифеніл)-2-пропен-1-ону (5) і кип'ятили 3 год (контроль за ТШХ). Охолодили, відфільтрували осад, промили ДМФА, етанолом. Вихід 0,7 г (75\%). $\mathrm{C}_{26} \mathrm{H}_{16} \mathrm{NO}_{5} \mathrm{~S}$. $T_{\text {пл }} 273-274{ }^{\circ} \mathrm{C}$ (з ДМФА). Спектр ЯМР ${ }^{1} \mathrm{H}$ (400 МГц, DMSO- $d_{6}-\mathrm{CCl}_{4}, \delta$, м. д., $J /$ Гц): 3,93 $\left(2 \mathrm{H}, \mathrm{c}, \mathrm{CH}_{2}\right), 6,99$ (1H, д, $\left.J=8,4, \mathrm{H}-6\right), 7,35\left(1 \mathrm{H}\right.$, т, 8,0, H-6'), 7,42-7,49 (3H, м, H-5',6", $\left.8^{\prime \prime}\right)$, 7,68-7,70 (2Н, м, Н-5,7"), 7,81 (1Н, с, Н-2"), 7,95 (1Н, д, $J=8,0$, Н-4'), 7,99 (1Н, д, $J=8,0$, Н-7'), 8,12 (1Н, д, $J=8,4, \mathrm{H}-5), 9,07$ (1Н, с, Н-4), 10,89 (1Н, уш. с, ОН). Мас-спектр, $m / z$ $\left(I_{\text {відн }}, \%\right): 454[\mathrm{MH}]^{+}(100)$.

7-[3-(1,3-Бензотіазол-2-іл)-7-гідрокси-2-оксо-2H-8-хроменілметил]-10-метил4-феніл-2H,6Н-пірано[3,2-g]хромен-2,6-діон (8). До розчину 0,08 г (0,2 ммоль) 3-(1,3бензотіазол-2-іл)-8-диметиламінометил-7-гідрокси-2H-2-хроменону (3) в 1 мл диметилформаміду додали 0,07 г (0,2 ммоль) 3-диметиламіно-1-(7-гідрокси-8-метил-2-оксо-4феніл-2H-6-хроменіл)-2-пропен-1-ону (6) і кип'ятили 1 год. Охолодили, відфільтрували осад, промили ДМФА, етанолом. Вихід 0,09 г (75\%). $\mathrm{C}_{36} \mathrm{H}_{21} \mathrm{NO}_{7} \mathrm{~S} . T_{\text {пл }}$ вище $300 \quad{ }^{\circ} \mathrm{C}$ (з ДМФА). Спектр ЯМР ${ }^{1} \mathrm{H}$ ( $400 \mathrm{M} ц, \mathrm{DMSO}-d_{6}, \delta$, м. д., J/Гц): 3,86 (2H, c, $\left.\mathrm{CH}_{2}\right), 6,46(1 \mathrm{H}, \mathrm{c}$, Н-3"), 6,99 (1Н, д, $J=8,0, \mathrm{H}-6), 7,42$ (1Н, т, $\left.J=8,4, \mathrm{H}-6^{\prime}\right), 7,51-7,60$ (6H, м, H-5', Ph), 7,81 (1Н, д, $J=7,6, \mathrm{H}-5), 7,95-8,02$ (3Н, м, Н-4', Н-5", Н-8"), 8,11 (1Н, д, $\left.J=8,4, \mathrm{H}-7^{\prime}\right), 9,09$ $(1 \mathrm{H}, \mathrm{c}, \mathrm{H}-4), 10,97$ (1Н, уш. с, ОН). Мас-спектр, $m / z\left(I_{\text {відн }} \%\right): 612[\mathrm{MH}]^{+}(100)$.

3-(1,3-Бензотіазол-2-іл)-7-гідрокси-8-[3-(2-гідроксифеніл)-1Н-4-піразолілметил]-2Н-2-хроменон (9). До суспензії 0,19 г (0,4 ммоль) 3-(1,3-бензотіазол-2-іл)-7гідрокси-8-(4-оксо-4H-3-хроменілметил)- $2 H$-2-хроменону (7) у 5 мл етанолу додали 0,1 мл (3 ммоль) гідразин-гідрату і кип'ятили 1.5 год (контроль за ТШХ). Охолодили, відфільтру- 
вали осад, промили етанолом. Вихід 0,11 г (59 \%). $\mathrm{C}_{26} \mathrm{H}_{17} \mathrm{~N}_{3} \mathrm{O}_{4} \mathrm{~S} . T_{\text {пл }}$ вище $300{ }^{\circ} \mathrm{C}$. Спектр ЯMP ${ }^{1} \mathrm{H}\left(400\right.$ МГц, DMSO- $d_{6}-\mathrm{CCl}_{4}, \delta$, м. д., J/Гц ): 4,20 (2H, c, CH $), 6,91-6,92\left(2 \mathrm{H}, \mathrm{M}, \mathrm{H}-6,3^{\prime \prime \prime}\right)$, 7,00-7,18 (3Н, м, Н-4"', $\left.5^{\prime \prime \prime}, 6^{\prime \prime \prime}\right), 7,36\left(1 \mathrm{H}, \mathrm{\text {т }} J=7,2, \mathrm{H}-6^{\prime}\right), 7,48\left(1 \mathrm{H}, \mathrm{т}, J=7,2, \mathrm{H}-5^{\prime}\right), 7,68$ (1Н, д, $J=6,4$, Н-5), 7,85 (1Н, уш. с, Н-5' ). 7,96 (1Н, д, J=8,4, Н-4'), 7,99 (1Н, д, J= 8,4, Н-7'), 9,09 (1H, с, H-4), 11,11 (1H, уш. с, 7-OH), 12,86 (1Н, уш. с, 2"'-ОН), NH обмінявся з $\mathrm{H}_{2} \mathrm{O}$. Мас-спектр, $m / z\left(I_{\text {відн }}, \%\right): 468[\mathrm{M}+\mathrm{H}]^{+}(100)$.

3-(1,3-Бензотіазол-2-іл)-7-гідрокси-8-[5-(2-гідроксифеніл)-4-ізоксазолілметил]2H-2-хроменон (10). До розчину 0,23 г (0,5 ммоль) 3-(1,3-бензотіазол-2-іл)-7-гідрокси-8(4-оксо-4H-3-хроменілметил)-2H-2-хроменону (7) в 1 мл піридину додали 0,1 г (1,5 ммоль) гідрохлориду гідроксиламіну і кип'ятили 5 год, охолодили, відфільтрували осад, промили водою, перекристалізували з діоксану. Вихід 0,18 г (78 \%). $\mathrm{C}_{26} \mathrm{H}_{16} \mathrm{~N}_{2} \mathrm{O}_{5} \mathrm{~S} . T_{\text {пл }}$ вище $300{ }^{\circ} \mathrm{C}$. Спектр ЯМР ${ }^{1} \mathrm{H}\left(400 \mathrm{MГц,} \mathrm{DMSO-} d_{6}-\mathrm{CCl}_{4}, \delta\right.$, м. д., $J /$ Г) $)$ 3,95 (2H, c, $\left.\mathrm{CH}_{2}\right), 6,89$ (1H, т, $J=$

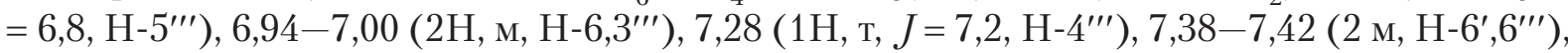
7,49 (1Н, т, $J=7,2, \mathrm{H}^{-5}$ ) , 7,68 (1Н, д, $\left.J=8,8, \mathrm{H}-5\right), 7,97$ (1Н, д, $\left.J=8,0, \mathrm{H}-4^{\prime}\right), 8,04$ (1Н, д, $\left.J=8,0, \mathrm{H}^{-7}{ }^{\prime}\right), 8,11$ (1H, c, H-3"'). 9,06 (1H, c, H-4), 9,89 (1H, c, 7-OH), 10,92 (1H, c, 2"'-OH). Мас-спектр, $m / z\left(I_{\text {відн }}, \%\right): 469[\mathrm{MH}]^{+}(100)$.

8-[2-аміно-4-(2-гідроксифеніл) -5-піримідинілметил]-3-(1,3-бензотіазол-2-іл)-7гідрокси-2Н-2-хроменон (11). До розчину 0,23 г (0,5 ммоль) 3-(1,3-бензотіазол-2-іл)-7гідрокси-8-(4-оксо-4H-3-хроменілметил)-2H-2-хроменону (9) у 2 мл ДМФА додали 0,09 г (0,5 ммоль) карбонату гуанідину і кип'ятили 6 год, охолодили, розбавили водою, нейтралізували АсОН, відфільтрували осад, перекристалізували із суміші ДМФА-ацетон. Вихід 0,13 г (53\%). $\mathrm{C}_{27} \mathrm{H}_{18} \mathrm{~N}_{4} \mathrm{O}_{4} \mathrm{~S} . T_{\text {пл }} 261-262{ }^{\circ} \mathrm{C}$. Спектр ЯМР ${ }^{1} \mathrm{H}\left(400\right.$ МГц, DMSO-d ${ }_{6}-\mathrm{CCl}_{4}$, б, м. д., J/Гц): 3,92 (2H, с, $\left.\mathrm{CH}_{2}\right), 6,21\left(2 \mathrm{H}, \mathrm{c}, \mathrm{NH}_{2}\right), 6,78\left(1 \mathrm{H}, \mathrm{T}, J=7,2, \mathrm{H}-5^{\prime \prime \prime}\right), 6,88-6,92(2 \mathrm{H}$, м, Н-3"',6), 7,13 (1Н, т, $J=7,2$, Н-4"' ), 7,22 (1Н, д, $\left.J=7,6, \mathrm{H}-6^{\prime \prime \prime}\right), 7,38$ (1Н, т, $\left.J=7,6, \mathrm{H}-6^{\prime}\right)$, 7,48 (1Н, т, $\left.J=7,6, \mathrm{H}^{-5} 5^{\prime}\right), 7,64$ (1Н, д, $\left.J=8,4, \mathrm{H}-5\right), 7,79\left(1 \mathrm{H}\right.$, с, $\left.\mathrm{H}^{\prime \prime}\right), 7,96$ (1Н, д, $\left.J=8,4, \mathrm{H}^{\prime} 4^{\prime}\right)$,

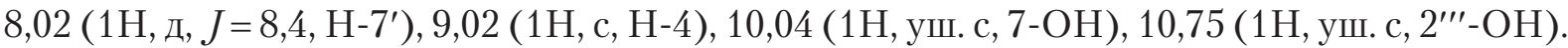
Мас-спектр, $m / z\left(I_{\text {відн }}, \%\right): 496[\mathrm{MH}]^{+}(100)$.

\section{3-(1,3-Бензотіазол-2-іл)-7-гідрокси-2-оксо-2Н-8-хроменкарбальдегід (12).}

Метод $A$. Розчин 0,53 г (1,5 ммоль) 3-(1,3-бензотіазол-2-іл)-8-диметиламінометил-7гідрокси-2H-2-хроменону (3) і 0,42 г (3 ммоль) уротропіну в 5 мл оцтової кислоти кип'ятили протягом 1 год. Гарячий розчин вилили у гарячий розчин 1,5 мл $\mathrm{HCl}$ i 1,5 мл води, розбавили 15 мл води. Через 1 год відфільтрували осад, перекристалізували з АсОН. Вихід 73 \%.

Метод В. Розчин 1,48 г (5 ммоль) 3-(1,3-бензотіазол-2-іл)-7-гідрокси-2H-2-хроменону (1) i 7 г (50 ммоль) уротропіну у 20 мл оцтової кислоти нагрівали на водяній бані протягом 6 год. Гарячий розчин вилили у гарячий розчин 12 мл $\mathrm{HCl}$ i 12 мл води, розбавили 40 мл води. Через 1 год відфільтрували осад, перекристалізували з АсОН. Вихід 85 \%. $\mathrm{C}_{17} \mathrm{H}_{9} \mathrm{NO}_{4} \mathrm{~S}$. $T_{\text {пл }} 234-235{ }^{\circ} \mathrm{C}\left(\right.$ з АсОН). Спектр ЯMP ${ }^{1} \mathrm{H}\left(\delta\right.$, м. ч., J/Гц): (400 МГц, DMSO- $d_{6}-\mathrm{CCl}_{4}, \delta, \mathrm{M}$. д., $J /$ Гц): 7,02 (1Н, д, $J=8,8, \mathrm{H}-6), 7,36$ (1H, т, $\left.J=7,6, \mathrm{H}^{\prime} 6^{\prime}\right), 7,46\left(1 \mathrm{H}\right.$, т, $\left.J=7,6, \mathrm{H}-5^{\prime}\right), 7,94$

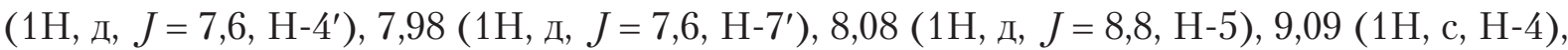
10,48 (1H, с, СНО), 12,19 (1Н, уш. с, ОН). Мас-спектр, $m / z\left(I_{\text {відн }}, \%\right): 324[\mathrm{MH}]^{+}(100)$.

3-(1,3-Бензотіазол-2-іл)-8-(4-нітробензоїл)-2Н-фуро[2,3-h]хромен-2-он (13). До розчину 0,32 г (1 ммоль) 3-(1,3-бензотіазол-2-іл)-7-гідрокси-2-оксо-2H-8-хроменкарбальдегіду (12) і 0,24 г (1 ммоль) 4-нітрофенацилброміду у 2 мл ДМФА додали 0,14 г (1 ммоль) 
$\mathrm{K}_{2} \mathrm{CO}_{3}$ та інтенсивно перемішували, нагріваючи $\left(100{ }^{\circ} \mathrm{C}\right)$ протягом 5 год, охолодили, розбавили водою (20 мл), нейтралізували $\mathrm{HCl}$, відфільтрували осад і перекристалізували 3 діоксану. Вихід $32 \% . \mathrm{C}_{25} \mathrm{H}_{12} \mathrm{~N}_{2} \mathrm{O}_{6} \mathrm{~S} . T_{\text {пл }}$ вище $300{ }^{\circ} \mathrm{C}$ (з діоксану). Спектр ЯМР ${ }^{1} \mathrm{H}$ (400 МГц, DMSO- $d_{6}$, $\delta$, м. д., J/Гц): 7,45 (1Н, т, $\left.J=8,0, \mathrm{H}^{\prime} 6^{\prime}\right), 7,55$ (1H, т, $\left.J=8,0, \mathrm{H}-5^{\prime}\right), 7,90$ (1Н, д, $J=$

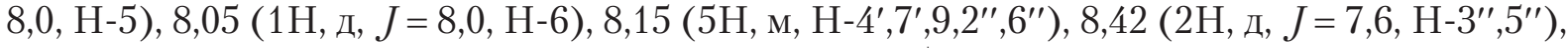
9,38 (1H, с, Н-4). Мас-спектр, $m / z\left(I_{\text {відн }}, \%\right): 469[\mathrm{MH}]^{+}(100)$.

Робота виконана за підтримки Міністерства освіти і науки України: грант Міністерства освіти і науки України для перспективного розвитку наукового напряму “Математичні науки та природничі науки” у Київському начіональному університеті ім. Тараса Шевченка.

\section{ЦИТОВАНА ЛІТЕРАТУРА}

1. Chao R.Y., Ding M.F., Chen J.Y., Lee C.C., Lin S.T. Preparation and characterization of substituted 3-benzothiazol-2-ylcoumarins. J. Chin. Chem. Soc. 2010. 57, № 2. P. 213-221. https://doi.org/10.1002/jccs.201000033

2. Zhang H., Li M., Feng W., Feng G. Rapid and selective detection of selenocysteine with a known readily available colorimetric and fluorescent turn-on probe. Dyes and Pigments. 2017. 149. P. 475-480. https://doi.org/10.1016/j.dyepig.2017.10.031

3. Wang C., Xu F., Niu Y., Wu Y., Sun Y., Peng Y., Liang L., Xu P. Synthesis and biological evaluations of 3-benzothiazol-2-yl coumarin derivatives as MEK1 inhibitors. Letters in drug design and discovery. 2013. 10, № 8. P. 727-732. https://doi.org/10.1691/ph.2019.9664

4. Khilya O.V., Frasinyuk M.S., Turov A.V., Khilya V.P. Chemistry of 3-hetarylcoumarins. 1. 3-(2-benzazolyl)coumarins. Chem. Het. Compd. 2001. 37, № 8. P. 1029-1037. https://doi.org/10.1023/A:1012704121345

5. Wolfbeis O.S, Koller E., Hochmuth P. The unusually strong effect of a 4-cyano group upon electronic spectra and dissociation constants of 3-substituted 7-hydroxycoumarin. Bull. Chem. Soc. Jpn. 1985. 58, № 2. P. 731-734. https://doi.org/10.1246/bcsj.58.731

6. Khoobi M., Ramazani A., Foroumadi A.R., Hamadi H., Hojjati Z., Shafiee A. Efficient microwave-assisted synthesis of 3-benzothiazolo and 3-benzothiazolino coumarin derivatives catalyzed by heteropoly acids. J. Iran. Chem. Soc. 2011. 8, № 4. P. 1036-1042. https://doi.org/10.1007/BF03246560

7. Roubinet B., Renard P.-Y., Romieu A. New insights into the water-solubilization of thiol-sensitive fluorogenic probes based on long-wavelength 7-hydroxycoumarin scaffolds. Dyes and Pigments. 2014. 110. P. 270-284. https://doi.org/10.1016/j.dyepig.2014.02.004

Надійшло до редакції 01.07.2021

\section{REFERENCES}

1. Chao, R. Y., Ding, M. F., Chen, J. Y., Lee, C. C. \& Lin, S. T. (2010). Preparation and characterization of substituted 3-benzothiazol-2-ylcoumarins. J. Chin. Chem. Soc., 57, No. 2, pp. 213-221. https://doi.org/10.1002/jccs.201000033

2. Zhang, H., Li, M., Feng, W. \& Feng, G. (2017). Rapid and selective detection of selenocysteine with a known readily available colorimetric and fluorescent turn-on probe. Dyes and Pigments, 149, pp. 475-480. https://doi.org/10.1016/j.dyepig.2017.10.031

3. Wang, C., Xu, F., Niu, Y., Wu, Y., Sun, Y., Peng, Y., Liang, L. \& Xu, P. (2013). Synthesis and biological evaluations of 3-benzothiazol-2-yl coumarin derivatives as MEK1 inhibitors. Letters in drug design and discovery, 10, No. 8, pp. 727-732. https://doi.org/10.1691/ph.2019.9664

4. Khilya, O. V., Frasinyuk, M. S., Turov, A. V. \& Khilya, V. P. (2001). Chemistry of 3-hetarylcoumarins. 1. 3-(2-benzazolyl)-coumarins. Chem. Het. Compd. 37, No. 8, pp. 1029-1037.

https://doi.org/10.1023/A:1012704121345 
5. Wolfbeis, O. S, Koller, E. \& Hochmuth, P. (1985). The unusually strong effect of a 4-cyano group upon electronic spectra and dissociation constants of 3-substituted 7-hydroxycoumarin. Bull. Chem. Soc. Jpn., 58, No. 2, pp. 731-734. https://doi.org/10.1246/bcsj.58.731

6. Khoobi, M., Ramazani. A., Foroumadi, A. R., Hamadi, H., Hojjati, Z. \& Shafiee, A. (2011). Efficient microwave-assisted synthesis of 3-benzothiazolo and 3-benzothiazolino coumarin derivatives catalyzed by heteropoly acids. J. Iran. Chem. Soc., 8, No. 4, pp. 1036-1042. https://doi.org/10.1007/BF03246560

7. Roubinet, B., Renard, P. -Y. \& Romieu, A. (2014). New insights into the water-solubilization of thiol-sensitive fluorogenic probes based on long-wavelength 7-hydroxycoumarin scaffolds. Dyes and Pigments, 110, pp. 270-284. https://doi.org/10.1016/j.dyepig.2014.02.004

Received 01.07.2021

T.V. Shokol ${ }^{1}$, https://orcid.org/0000-0002-8483-703X

A.V. Suprun ${ }^{1}$

E.K. Hlibov ${ }^{1,2}$, https://orcid.org/0000-0002-5987-9510

V.S. Moskvina ${ }^{1}$, https://orcid.org/0000-0001-5556-9147

V.P. Khilya ${ }^{1}$, https://orcid.org/0000-0001-9438-572X

${ }^{1}$ Taras Shevchenko National University of Kyiv

${ }^{2}$ Enamine Ltd., Kyiv

E-mail: shokol_tv@univ.kiev.ua

\section{MODIFICATIONS OF 7-HYDROXY-3-(BENZOTHIAZOL-2-YL)COUMARIN}

This paper is devoted to 7-hydroxy-3-(benzothiazol-2-yl)coumarin modifications using the dimethylaminomethyl and formyl groups introduced in 8 position, useful for further structural transformations. Derivatives of the dihydrooxazinocoumarin system were obtained by aminomethylation of 7-hydroxy-3-(benzothiazol-2-yl) coumarin under the classical Mannich reaction conditions using an excess of formalin.

Starting from 8-dialkylaminomethyl-7-hydroxy-3-(benzothiazol-2-yl)coumarin the corresponding Mannich bases were synthesized by transamination with benzylamines, homoisoflavone derivatives were obtained as a result of the interaction with $o$-hydroxyarene enaminoketones and 3-(benzothiazol-2-yl)-7-hydroxy-8-formylcoumarin was obtained under the Duff reaction conditions. The latter in the reaction with 4-nitrophenacyl bromide formed the furo[2,3- $h]$ coumarin system derivative. The recyclizations of 3-(benzothiazol-2-yl)-7-hydroxy8-(4-oxo-4H-3-chromenylmethyl)-2H-2-chromenone under the action of binucleophiles were studied.

Keywords: 7-hydroxy-3-benzothiazolylcoumarin, aminomethylation, formylation, homoisoflavones, recyclization. 